\title{
Polityka publiczna w partnerstwie - nowa Irlandzka Umowa Centralna (Lansdowne Road Agreement)
}

\begin{abstract}
Streszczenie
Po okresie funkcjonowania partnerstwa społecznego w szerokiej tematycznie formule irlandzkie stosunki przemysłowe weszły w nowy etap. Można mówić o ukształtowaniu się nowego podejścia do tworzenia relacji rządu z partnerami społecznymi. Jednym z jego przejawów jest wprowadzenie mechanizmu porozumień tylko w zakresie sektora publicznego. Do takich porozumień zalicza się Umowę stabilizacyjną w sprawie sektora publicznego 2013-2018 - Lansdowne Road (Public Service Stability Agreement 2013-2018 - Lansdowne Road Agreement, LRA). Stąd też głównym celem artykułu jest prezentacja tego porozumienia $\mathrm{z}$ uwzględnieniem analizy ważniejszych jego zapisów oraz atmosfery wokół niego panującej. Formułuję hipotezę głoszącą, że irlandzkie centralne umowy uległy znaczącej zmianie. Stawiam dwa pytania badawcze: (1) czy redukcji uległa agenda umów centralnych i jaka jest w związku z tym problematyka dotykana przez LRA?, oraz (2) jakie emocje panują wokół porozumienia Lansdowne Road?
\end{abstract}

Słowa kluczowe: służba publiczna, umowa, relacje przemysłowe, dialog społeczny, Irlandia

\section{Public Policy in Partnership - a New Irish Central Agreement (Lansdowne Road Agreement)}

\begin{abstract}
Ireland's industrial relations have come into a new stage of relationship between the government and social partners after a period of effective social partnership functioning. One of the symptoms of this new approach is a mechanism based on the public service agreements. The Public Service Stability Agreement 2013-2018 - Lansdowne Road Agreement (LRA) can be an example of that kind of pacts. The main goal of this paper, therefore, is a presentation of the agreement including an analysis of its significant records
\end{abstract}


and atmosphere around the pact. To achieve the goal the paper is structured as follows: the introduction includes a short description of social pacts as well as new public service agreements. The second part draws our attention to LRA's records. The third section discusses the attitude of different actors of industrial relations to Lansdowne Road Agreement. Finally, the conclusion is a short summary giving answers to the researched questions.

Keywords: public service, agreement, industrial relations, social dialogue, Ireland

Po okresie obowiązywania w Irlandii do 2008 r. szerokiego partnerstwa społecznego zostały tam wygaszone wielostronne pakty społeczne, które rząd zawierał ze związkami zawodowymi, organizacjami pracodawców, stowarzyszeniami rolniczymi oraz organizacjami sektora społecznościowego i wolontaryjnego. Od kilku lat nowe porozumienia rządu ze związkami zawodowymi dotyczą tylko zagadnień reform w sektorze publicznym. Taką nową formułą porozumień jest Umowa stabilizacyjna w sprawie sektora publicznego 2013-2018 (Public Service Stability Agreement 2013-2018 - Lansdowne Road Agreement, LRA), którą poniżej analizuję, co jest głównym celem artykułu. Uwzględniam jej najważniejsze zapisy, ale także atmosferę panującą wokół tego porozumienia.

Dlatego też przyjmuję hipotezę, że irlandzkie centralne umowy społeczne uległy znaczącej zmianie. Stawiam dwa pytania badawcze dotyczące: (1) skali redukcji agendy umów centralnych i jaką w związku z tym problematykę obejmuje LRA oraz dotyczące (2) typu emocji panujących wokół porozumienia Lansdowne Road.

Konstrukcja artykułu została ułożona następująco: we wstępie zamieszczono analityczny opis paktów społecznych i nowych umów centralnych w Irlandii, w drugiej części prześledzono zapisy Umowy stabilizacyjnej w sprawie sektora 2013-2018, w trzeciej zaś zaprezentowano opinie o LRA, a w podsumowaniu luźno odpowiedziano na pytania badawcze.

Przeprowadzam analizę poszczególnych umów służby publicznej. W tym celu wykorzystuję publikacje prasowe, a także teksty specjalistyczne ze stron internetowych, jakie oferuje Europejska Fundacja na Rzecz Poprawy Warunków Życia i Pracy (Eurofound). 
Tabela 1. Umowy społeczne w Irlandii od 1987 roku

\begin{tabular}{|c|c|c|}
\hline & Umowa społeczna & Opis \\
\hline \multirow{7}{*}{ 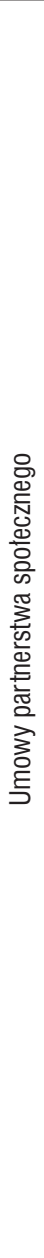 } & $\begin{array}{l}\text { Program Narodowego Ożywienia } \\
\text { (Programme for National Recovery, PNR, } \\
\text { 1987-1990) }\end{array}$ & $\begin{array}{l}\text { Odnowa irlandzkiej gospodarki oraz poprawa sprawiedliwości } \\
\text { społecznej }\end{array}$ \\
\hline & $\begin{array}{l}\text { Program na rzecz Postępu Ekonomicznego } \\
\text { i Społecznego (Programme for Economic and } \\
\text { Social Progress, PESP, 1991-1993) }\end{array}$ & $\begin{array}{l}\text { Trwały wzrost gospodarczy, wytwarzanie większego } \\
\text { dochodu, by zmniejszyć przepaść w standardzie życia } \\
\text { pomiędzy Irlandią a resztą Wspólnoty Europejskiej, wzrost } \\
\text { zatrudnienia, uderzenie w długoterminowe bezrobocie, } \\
\text { rozwój lepszych praw społecznych, promocja społecznej } \\
\text { odpowiedzialności, rozwój pracowniczej partycypacji, praw } \\
\text { kobiet, praw konsumenta }\end{array}$ \\
\hline & $\begin{array}{l}\text { Program na rzecz Konkurencyjności i Pracy } \\
\text { (Programme for Competitiveness and Work, } \\
\text { PCW, 1994-1996) }\end{array}$ & Wzrost liczby osób pracujących, redukcja bezrobocia \\
\hline & $\begin{array}{l}\text { Partnerstwo } 2000 \text { (Partnership 2000, P2, } \\
\text { 1997-2000) }\end{array}$ & $\begin{array}{l}\text { Kontynuowanie rozwoju wydajnej, nowoczesnej gospodarki } \\
\text { zdolnej do wysokiego i zrównoważonego wzrostu } \\
\text { ekonomicznego i zatrudnienia oraz działania w środowisku } \\
\text { międzynarodowej konkurencji }\end{array}$ \\
\hline & $\begin{array}{l}\text { Program na rzecz Koniunktury i Sprawiedliwości } \\
\text { (Programme for Prosperity and Fairness, PPF } \\
(2000-2003)\end{array}$ & $\begin{array}{l}\text { Budowanie sprawiedliwego, inkluzyjnego społeczeństwa } \\
\text { w Irlandii opierającego się na: dynamicznej i konkurencyjnej } \\
\text { gospodarce, pełnym zatrudnieniu i eliminacji długotrwałego } \\
\text { bezrobocia, równych możliwościach, uczeniu się przez } \\
\text { całe życie, adaptacji do społeczeństwa informacyjnego, } \\
\text { promocji badań i rozwoju, zrównoważonym i trwałym rozwoju } \\
\text { pomiędzy i wewnątrz regionów oraz pomiędzy obszarami } \\
\text { miejskimi i wiejskimi, kulturze przedsiębiorczości, silnej } \\
\text { pozycji Irlandii w UE i społeczności międzynarodowej }\end{array}$ \\
\hline & $\begin{array}{l}\text { Podtrzymanie Postępu (Sustaining Progress, SP, } \\
\text { 2003-2005) }\end{array}$ & $\begin{array}{l}\text { Gospodarcza inkluzja poprzez pełne zatrudnienie, rozwój } \\
\text { gospodarczy, który jest zrównoważony społecznie } \\
\text { i środowiskowo, społeczna inkluzja, zobowiązanie do } \\
\text { społecznej sprawiedliwości, dostosowanie do zmiany }\end{array}$ \\
\hline & $\begin{array}{l}\text { W stronę roku 2016. Dziesięcioletnia Ramowa } \\
\text { Umowa Partnerstwa Społecznego 2006-2015 } \\
\text { (Towards 2016. Ten-Year Framework Social } \\
\text { Partnership Agreement 2006-2015, T 2016, } \\
\text { 2006-2016) }\end{array}$ & $\begin{array}{l}\text { Dynamiczne, umiędzynarodowione, uczestniczące } \\
\text { społeczeństwo i gospodarka, w której istnieje silne } \\
\text { zobowiązanie do społecznej sprawiedliwości, gdzie } \\
\text { rozwój gospodarczy jest zrównoważony środowiskowo } \\
\text { i konkurencyjny międzynarodowo }\end{array}$ \\
\hline 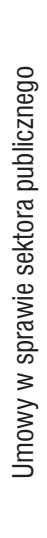 & $\begin{array}{l}\text { Umowa w sprawie sektora publicznego } \\
\text { 2010-2014 (Public Service Agreement } \\
\text { 2010-2014 - Croke Park Agreement) }\end{array}$ & $\begin{array}{l}\text { Uznanie roli służby publicznej w odbudowie gospodarki } \\
\text { po kryzysie. Konieczność restrukturyzacji i reorganizacji } \\
\text { sektora publicznego. Potrzeba ograniczenia liczby } \\
\text { pracowników służby publicznej, przy jednoczesnym } \\
\text { zobowiązaniu rządu do nieprzeprowadzania przymusowych } \\
\text { redukcji etatów i możliwości zaoferowania mechanizmów } \\
\text { dobrowolnego wychodzenia pracowników z sektora } \\
\text { publicznego. Współpraca stron na podstawie umów } \\
\text { sektorowych. Brak dodatkowych cięć w stawkach płacowych } \\
\text { w czasie trwania umowy. Związki zawodowe i pracodawcy } \\
\text { zobowiązują się do kooperacyjnego rozwiązywania } \\
\text { kwestii spornych odnoszących się do umowy. Związki } \\
\text { zawodowe zobowiązały się do niewysuwania żądań } \\
\text { płacowych i poprawy warunków pracy. Podejmowanie } \\
\text { akcji przemysłowych w kwestiach objętych umową przez } \\
\text { pracodawców, związki zawodowe jest wykluczone. }\end{array}$ \\
\hline
\end{tabular}




\begin{tabular}{|c|c|c|}
\hline & Umowa społeczna & Opis \\
\hline \multirow[t]{2}{*}{ 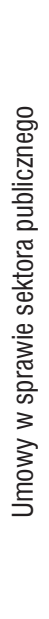 } & $\begin{array}{l}\text { Umowa stabilizacyjna w sprawie sektora } \\
\text { publicznego 2013-2016 (Public Service Stability } \\
\text { Agreement 2013-2016) - Haddington Road } \\
\text { Agreement }\end{array}$ & $\begin{array}{l}\text { Sposoby ulepszenia służby publicznej: płaca i produktywność } \\
\text { - dodatkowe godziny pracy, nadgodziny, premie, } \\
\text { wyższe płace, dodatki, diety, emerytury, zewnętrzne } \\
\text { konsultacje, tabela płac dla nowych pracowników. Środki } \\
\text { do zaoszczędzenia } 1 \text { mld euro w płacach i emeryturach } \\
\text { sektora publicznego do } 2015 \text { r. Reforma pracy w sferze } \\
\text { publicznej: dalsza redukcja zatrudnienia, przesunięcia } \\
\text { pracowników, restrukturyzacja zatrudnienia, usprawnienie } \\
\text { zarządzania wydajnością, podział pracy, elastyczny czas } \\
\text { pracy, outsourcing. Mechanizmy wspierające odejście ze } \\
\text { służby publicznej stosowane w celu redukcji zatrudnienia } \\
\text { w tym obszarze. Wdrożenie umowy: rozwiązywanie sporów, } \\
\text { nietypowe sytuacje, nadzór nad umową. Umowy sektorowe } \\
\text { - porozumienia z poszczególnymi sektorami służby publicznej }\end{array}$ \\
\hline & $\begin{array}{l}\text { Umowa stabilizacyjna w sprawie sektora } \\
\text { publicznego 2013-2018 (Public Service Stability } \\
\text { Agreement 2013-2018 - Lansdowne Road } \\
\text { Agreement) }\end{array}$ & Zob. poniżej. \\
\hline
\end{tabular}

Źródło: opracowanie na podstawie: K. Kichewko, Dialog społeczny w Irlandii, w: Polska w dialogu. Tradycja, zmiany, porównanie, perspektywy, red. A. Zybała, Centrum Partnerstwa Społecznego „Dialog”, Ministerstwo Rodziny, Pracy i Polityki Społecznej, Warszawa 2016, s. 191-195; Public Service Agreement 2010-2014, Prn A10/0896, June 2010; Public Service Stability Agreement 2013-2016. The Haddington Road Agreement, LRC Proposals, May 2013.

\section{Treść umowy Lansdowne Road Agreement (LRA)}

Umowa stabilizacyjna w sprawie sektora publicznego 2013-2018 została zaaprobowana przez Irlandzki Kongres Związków Zawodowych (Irish Congress of Trade Unions) we wrześniu 2015 r. Była ona negocjowana przy wsparciu Komisji Stosunków Pracy (Labour Relations Commission, LRC) ${ }^{1}$. Jej istotnym walorem jest to, że jako pierwsza po kilkuletnim zamrożeniu płac i w rzeczywistości cięciu w płacach nominalnych podjęto tematykę wzrostu płac w sektorze publicznym.

Treść umowy LRA rozpoczyna się od stwierdzenia, że irlandzcy urzędnicy publiczni mieli znaczący wpływ na pobudzenie i uzdrowienie tamtejszej gospodarki.

1 LRC była jedną z najważniejszych instytucji konsultacyjno-doradczych irlandzkich relacji przemysłowych, wspierającą proces dobrowolnego rozwiązywania sporów pomiędzy pracodawcami i pracownikami (zob. szerz. o LRC: K. Kichewko, Komisja Stosunków Pracy jako mechanizm rozwiazywania konfliktów pracowniczych w Irlandii, „Praca i Zabezpieczenie Społeczne” 2015, nr 1, s. 8-13). Od 1 października 2015 r. role i funkcje LRC przejęła Komisja Stosunków w Miejscu Pracy (Workplace Relations Commission, WRC), której powierzono także zadania pełnione wcześniej przez Narodowy Urząd ds. Praw Pracowniczych (National Employment Rights Authority, NERA), Trybunał ds. Równości (Equality Tribunal, ET), Służbę Komisarzy Prawnych (Rights Commissioners Service, RCS) oraz Trybunał Odwoławczy ds. Zatrudnienia (Employment Appeals Tribunal, EAT) w pierwszej instancji (skargi i skierowania). 
Stało się to możliwe dzięki reformom służby publicznej, a w szczególności zastosowanym środkom w zakresie płac i emerytur w tej sferze, krótko mówiąc redukcji $\mathrm{w}$ tym obszarze.

Właśnie reformę służby publicznej podaje się w omawianym dokumencie jako centralny element walki z kryzysem. A jako główny cel owej reformy wymienia się doprowadzenie do tego, aby sektor publiczny mógł zaoferować lepsze standardy swojej pracy obywatelom i interesariuszom, w tym biznesowi i samym urzędnikom publicznym ${ }^{2}$. Chodzi tu o zwiększenie dostępności instytucji publicznych dla obywateli, zapewnienie przystępniejszej informacji, otwartości i transparentności decyzji przez nie podejmowanych.

Zapowiedziano także redukcję obciążeń administracyjnych, które spadają na obywateli. Ma to nastąpić poprzez usprawnienie kanałów dostarczania, a także uelastycznienie koordynowania i planowania usług. Zapowiedziano lepsze wykorzystanie technologii, analizowanie danych, co ma umożliwić dostarczanie lepszych usług w sektorze edukacji, zdrowia czy innych obszarach. Na zwiększenie wydajności pracy w sektorze publicznym, jak podaje umowa, wpływać będzie także inwestycja w pracowników, którzy powinni poprawiać swój potencjał, umiejętności i kompetencje przywódcze, by sprostać nie tylko obecnym, ale także przyszłym wyzwaniom. Stanie się to możliwie poprzez tworzenie warunków do szkolenia i ciągłego rozwoju urzędników.

Strony uzgodniły, że dojdzie do przedłużenia porozumienia, które zawarte zostało na lata 2013-2016 (Haddington Road Agreement). Będzie ono obowiązywało do września $2018 \mathrm{r}$. Strony potwierdziły potrzebę zapewnienia wysokiej jakości działań sektora publicznego. Uznały przy tym konieczność przeprowadzenia zmian w sferze publicznej opartych na współdziałaniu i konsultacjach, by w ten sposób usprawnić usługi publiczne.

Umowa zawiera zapowiedź realizacji - prócz Planu Reformy Służby Publicznej na lata 2014-2016 (Public Service Reform Plan) różnych programów działań, w tym: - w służbie cywilnej - Plan Odnowy Służby Cywilnej (Civil Service Renewal Plan), - w sektorze edukacji - Dodatkowy Plan Edukacyjny i Szkoleniowy (Further Educational and Training Strategy), Reformę Programową w Szkołach (Curricular Reform within Schools), Przegląd Praktyk i Szkoleń w Irlandii (Review of Apprenticeship Training in Ireland), Narodową Strategię dla Edukacji Wyższej do 2030 r. (National Strategy for Higher Education to 2030), Narodową Strategię Poprawienia Umiejętności Pisania, Czytania i Liczenia na lata 2011-2020 (National Strategy to Improve Literacy and Numeracy 2011-2020),

2 Public Service Stability Agreement 2013-2018. The Lansdowne Road Agreement, The Labour Relations Commission, 29.05.2015, s. 3. 
- w sektorze samorządowym - Program Działań na rzecz Efektywnego Samorządu - Po Pierwsze Ludzie (Action Programme for Effective Local Government - Putting People First), Irlandzki Program Wodny (Irish Water Programme),

- w sektorze zdrowotnym - Strategiczna Rama Przyszłego Zdrowia dla reformy służby zdrowia (Future Health Strategic Framework) sprzężona ze strukturalną reformą wspierającą wysoką jakość opieki i zwiększenie efektów zdrowotnych,

- w sektorze sprawiedliwości - Przegląd Służby Policyjnej (Review of Garda Síochána) $)^{3}$.

Program reformy sektora publicznego zakłada wdrażanie środków zmierzających do zapewnienia lepszej produktywności i jakości usług publicznych. Środkiem realizacji celów ma być wprowadzenie elastycznych godzin pracy, co ma zapewnić sprawniejszą odpowiedź na potrzeby publiczne, lepsze wykorzystanie technologii, konsolidację i reorganizację pracy. Nacisk położono na dostarczanie usług cyfrowo, współpracę w ramach sektora publicznego, wypracowanie innowacyjnych modeli dostarczania usług. Istotnym czynnikiem zmian w sektorze publicznym pozostaje osiągnięcie wyższych standardów działania tej sfery poprzez sprawniejsze zarządzanie zasobami znajdującymi się w jej ramach i zwiększanie potencjału pracowników. To zaś możliwe będzie dzięki zmodernizowaniu zatrudnienia i zastosowaniu nowoczesnych praktyk zarządzania personelem.

Strony umowy zobowiązały się również do stosowania pewnych mechanizmów rozwiązywania sporów. I tak uznano konieczność:

(1) utrzymania stabilnych relacji przemysłowych i dobrego zarządzania nimi,

(2) zapewnienia dobrze rozwiniętego kanału komunikacji,

(3) poszukiwania rozwiązania problemów zanim dojdzie do eskalacji sporu przemysłowego,

(4) rozwiązywania kwestii spornych niezwłocznie,

(5) kooperacji w implementowaniu zmian,

(6) tam, gdzie strony nie mogą dojść do porozumienia w ciągu sześciu tygodni należy zwrócić się do odpowiednich instytucji koncyliacyjnych lub zastosować mechanizm uzgodnieniowy, wyniki ich są wiążące i ostateczne $e^{4}$.

Ustalono również, że strona pracownicza nie będzie wysuwać żądań płacowych w okresie trwania umowy, jak i to, że wyklucza się strajki i inne akcje w czasie obowiązywania porozumienia.

W najważniejszym punkcie umowy, mówiącym o płacach, wskazano, że większość personelu sektora publicznego otrzyma 2 tys. euro podwyżki w trzech fazach

3 Ibidem, s. 5.

4 Ibidem, s. 8. 
pomiędzy styczniem 2016 a wrześniem 2017 r.; 1 tys. euro podwyżki płacy zaplanowanej na 2017 r. będzie obejmować tylko te osoby, których dochód jest niższy niż 65 tys. euro rocznie; urzędnicy zarabiający powyżej 100 tys. euro rocznie będą podlegać cięciom płacowym zgodnie z Umową Haddington Road 2013 w przedłużonych trzech fazach, rozpoczynając od 2017 r.; większość emerytowanego personelu służby publicznej otrzyma około 1680 euro podwyżki w ciągu następnych trzech lat ${ }^{5}$.

Wątpliwości odnoszące się do implementacji i interpretacji zapisów porozumienia będą rozstrzygane na spotkaniach grupy, w skład której wchodzą przedstawiciele Zarządu Służby Publicznej (Public Service Management) i Komisji Służby Publicznej Irlandzkiego Kongresu Związków Zawodowych (Public Services Committee of Irish Congress of Trade Unions, PSC ICTU). A zatem tam, gdzie pojawiają się niejasności co do treści umowy, niezgodność i wątpliwości co do mechanizmów rozwiązywania sporów, tam wspomniana grupa będzie podejmowała działania mające na celu korygowanie sytuacji problemowych.

\section{LRA - kwestia sporna?}

Lansdowne Road Agreement nie jest prostą umową zawartą przez pracowników publicznych z rządem. Wzbudza i wzbudzała ona wiele kontrowersji jeszcze przed jej podpisaniem. Niektóre związki zawodowe były przeciwne umowie. Za odrzuceniem porozumienia opowiedziały się $\mathrm{w}$ głosowaniu organizacje nauczycieli drugiego poziomu (Stowarzyszenie Nauczycieli Drugiego Poziomu Nauczania w Irlandii - Association of Secondary Teachers in Ireland, ASTI oraz Związek Zawodowy Nauczycieli Irlandii - Teachers' Union of Ireland, TUI). Jednocześnie nauczyciele pierwszego stopnia edukacji zaakceptowali porozumienie Lansdowne Road'.

Negatywny stosunek do porozumienia wyrazili członkowie reprezentujący grupy lepiej zarabiających funkcjonariuszy, takich jak wyżsi urzędnicy, lekarze i weterynarze. Domagali się odrzucenia umowy, choć akurat organizacje, które ich reprezentują, zaakceptowały umowę.

5 M. Wall za K. Kichewko, Dialog społeczny w Irlandii, w: Polska w dialogu. Tradycja, zmiany, porównanie, perspektywy, red. A. Zybała, Centrum Partnerstwa Społecznego „Dialog”, Ministerstwo Rodziny, Pracy i Polityki Społecznej, Warszawa 2016, s. 198.

6 M. Wall, Teachers Could Lose $€ 800$ if Unions Fail to Back Pact, "The Irish Times", 17.09.2015, http://www.irishtimes.com/news/ireland/irish-news/teachers-could-lose-800-if-unions-fail-to-back-pact-1.2354342, dostęp 12.04.2016. 
Pomimo sprzeciwów ze strony niektórych organizacji należących do Komisji Służby Publicznej Irlandzkiego Kongresu Związków Zawodowych ${ }^{7}$ umowa została zaakceptowana. Zdaniem Shay Cody, sekretarza generalnego Irlandzkiego Związku Zawodowego Publicznych Urzędników Samorządowych i Służby Cywilnej (Irish Municipal Public and Civil Trade Union, IMPACT) Umowa stabilizacyjna w sprawie sektora publicznego 2013-2018 była ważnym krokiem na rzecz pracowników po siedmiu latach cięć płacowych. Podkreślił, że podwyższenie płac we wszystkich sektorach jest decydującym elementem dalszego uzdrawiania gospodarki kraju

Z kolei Brendan Howlin, były minister wydatków publicznych i reform, stwierdził, że LRA tworzy właściwy balans pomiędzy aspiracjami urzędników publicznych w zakresie podwyżki płac a podtrzymaniem dobrej kondycji finansów publicznych kraju oraz wzmacnia zobowiązanie urzędników publicznych do szerokiej reformy w służbie publicznej'.

Nie brakuje również słów krytyki wobec umowy. W wątpliwość podaje się jej wykonanie, zwłaszcza w zakresie płac. Derek Mullen, zastępca sekretarza generalnego Związku Zawodowego Służby Publicznej i Cywilnej (Civil Public and Service Union, CPSU) zaznacza, że ludzie postrzegają LRA jako start w odbudowie płac w sektorze publicznym, ale pytają, kiedy ujrzą główny kurs tego procesu ${ }^{10}$. Podobnie Tom Geraghty, sekretarz generalny Związku Wykonawczego Służby Publicznej (Public Service Executive Union, PSEU) wskazuje, że polityka płacowa może nie być taka, jaka została zaplanowana przez rząd i jednocześnie dodaje, że wyższy poziom wzrostu pociągnie za sobą żądania przyspieszenia procesu odbudowy płac ${ }^{11}$.

Z kolei prezydent negatywnie nastawionego do umowy Związku Zawodowego Nauczycieli Irlandii Gerry Quinn agitował na rzecz zastąpienia porozumienia innym, by zapewnić faktyczny wzrost $\mathrm{w}$ płacach i emeryturach w sektorze publicznym ${ }^{12}$. Na podobne zarzuty odpowiada sekretarz generalny Departamentu Wydatków

7 M. Wall, Public Service Pay Increase Deal to Be Formally Ratified, “The Irish Times”, 16.09.2015, http://www.irishtimes.com/news/ireland/irish-news/public-service-pay-increase-deal-to-be-formallyratified-1.2353768, dostęp 12.04.2016.

8 S. Cody za: B. Sheehan, Ireland: New Public Sector Agreement Passed, Eurofound, http://www. eurofound.europa.eu/observatories/eurwork/articles/industrial-relations/ireland-new-public-sector-agreement-passed, dostęp 17.05.2016.

9 B. Howlin za: B. Sheehan, Ireland: Public Sector Pay Restoration Talks Look Set to Succeed, Eurofound, https://www.eurofound.europa.eu/pl/observatories/eurwork/articles/industrial-relations-law-and-regulation/ireland-public-sector-pay-restoration-talks-look-set-to-succeed, dostęp 17.05.2016.

10 D. Mullen za: M. Wall, Lansdowne Road Pay Pact 'Creaking at the Edges', "The Irish Times", 22.03.2016, http://www.irishtimes.com/news/ireland/irish-news/lansdowne-road-pay-pact-creakingat-the-edges-1.2582108, dostęp 12.04.2016.

11 T. Geraghty za: ibidem.

12 Zob. szerz.: RTÉ, TUI President Calls for Lansdowne Road Replacement, 30.03.2016, http://www. rte.ie/news/2016/0330/778293-tui-conference-students/, dostęp 12.04.2016. 
Publicznych i Reform (Department of Public Expenditure and Reform) Robert Watt stwierdzając, że nie przewiduje on, by LRA podlegała nawet przeglądowi i konkluduje, iż „umowa była umową"13.

$* * *$

Umowa stabilizacyjna w sprawie sektora publicznego 2013-2018, zwana Umową Lansdowne Road, potwierdza pragmatyczność rozwiązań przyjmowanych przez irlandzkich partnerów społecznych w ramach tamtejszego modelu stosunków przemysłowych. Zawsze miały one na celu dopasowanie polityki do okoliczności i realiów, w których znajdowała się irlandzka gospodarka.

Porzucając jeden format umów na rzecz innego, szukano tam takiej konstelacji na linii rząd - partnerzy społeczni, która w danych warunkach będzie maksymalnie użyteczna. Kierując się tą zasadą pragmatyczności, w obecnej sytuacji partnerzy społeczni nie sięgają już po wielostronny mechanizm uzgodnień centralnych (jak w wypadku paktów społecznych). Skupiają się na umowach rządu z pracownikami sektora publicznego. Dlatego na pierwsze pytanie badawcze należy odpowiedzieć stwierdzeniem o znaczącym uszczupleniu zakresu centralnych porozumień, co wiąże się z redukcją tematyki porozumień. Nie obejmuje ona tak szerokiej agendy spraw społeczno-gospodarczych, jaką znaleźć można w umowach partnerstwa społecznego, ale dotyczy konkretnych kwestii polepszania sposobu funkcjonowania sektora publicznego. Z kolei, odpowiadając na drugie pytanie, nie pozostaje nic innego, jak uznanie, że „okrojenie” umów nie implikuje od razu zgody i powszechnej ich aprobaty wśród partnerów dialogu.

\section{Bibliografia}

Kichewko K., Dialog społeczny w Irlandii, w: Polska w dialogu. Tradycja, zmiany, porównanie, perspektywy, red. A. Zybała, Centrum Partnerstwa Społecznego „Dialog”, Ministerstwo Rodziny, Pracy i Polityki Społecznej, Warszawa 2016.

Kichewko K., Komisja Stosunków Pracy jako mechanizm rozwiązywania konfliktów pracowniczych w Irlandii, „Praca i Zabezpieczenie Społeczne” 2015, nr 1.

Public Service Agreement 2010-2014, Prn A10/0896, June 2010.

Public Service Stability Agreement 2013-2016. The Haddington Road Agreement, LRC Proposals, May 2013.

13 R. Watt za: RTÉ, Department Responds to Call for LRA to be Revisited, 5.04.2016, http://www.rte. ie/news/2016/0405/779520-mulvey-lansdowne-pay/, dostęp 12.04.2016. 
Public Service Stability Agreement 2013-2018. The Lansdowne Road Agreement, The Labour Relations Commission, 29.05.2015.

RTÉ, TUI President Calls for Lansdowne Road Replacement, 30.03.2016, http://www.rte. ie/news/2016/0330/778293-tui-conference-students/, dostęp 12.04.2016.

RTÉ, Department Responds to Call for LRA to be Revisited, 5.04.2016, http://www.rte.ie/news/ 2016/0405/779520-mulvey-lansdowne-pay/, dostęp 12.04.2016.

Sheehan B., Ireland: New Public Sector Agreement Passed, Eurofound, http://www.eurofound. europa.eu/observatories/eurwork/articles/industrial-relations/ireland-new-public-sectoragreement-passed, dostęp 17.05.2016.

Sheehan B., Ireland: Public Sector Pay Restoration Talks Look Set to Succeed, Eurofound, https://www.eurofound.europa.eu/pl/observatories/eurwork/articles/industrial-relationslaw-and-regulation/ireland-public-sector-pay-restoration-talks-look-set-to-succeed, dostęp 17.05.2016.

Wall M., Lansdowne Road Pay Pact 'Creaking at the Edges', “The Irish Times”, 22.03.2016, http:// www.irishtimes.com/news/ireland/irish-news/lansdowne-road-pay-pact-creaking-at-theedges-1.2582108, dostęp 12.04.2016.

Wall M., Public Service Pay Increase Deal to Be Formally Ratified, “The Irish Times”, 16.09.2015, http://www.irishtimes.com/news/ireland/irish-news/public-service-pay-increase-deal-tobe-formally-ratified-1.2353768, dostęp 12.04.2016.

Wall M., Teachers Could Lose $€ 800$ if Unions Fail to Back Pact, “The Irish Times”, 17.09.2015, http://www.irishtimes.com/news/ireland/irish-news/teachers-could-lose-800-if-unionsfail-to-back-pact-1.2354342, dostęp 12.04.2016. 